\title{
Half-sandwich nickel(II) complexes bearing 1,3-di(cycloalkyl)imidazol-2-ylidene ligands
}

\author{
Johnathon Yau, Kaarel E. Hunt, Laura McDougall, Alan R. Kennedy and David J. Nelson *
}

\author{
Full Research Paper \\ Address: \\ WestCHEM Department of Pure and Applied Chemistry, University of \\ Strathclyde, Thomas Graham Building, 295 Cathedral Street, \\ Glasgow G1 1XL, UK \\ Email: \\ David J. Nelson ${ }^{*}$ - david.nelson@strath.ac.uk \\ * Corresponding author \\ Keywords: \\ catalysis; cross-coupling; $\mathrm{N}$-heterocyclic carbenes; nickel
}

Beilstein J. Org. Chem. 2015, 11, 2171-2178.

doi:10.3762/bjoc. 11.235

Received: 07 September 2015

Accepted: 27 October 2015

Published: 12 November 2015

This article is part of the Thematic Series "N-Heterocyclic carbenes".

Guest Editor: S. P. Nolan

(c) 2015 Yau et al; licensee Beilstein-Institut. License and terms: see end of document.

\begin{abstract}
Two new nickel catalysts have been prepared using a convenient procedure where nickelocene, the $\mathrm{NHC} \cdot \mathrm{HBF}_{4}$ salts, and $\left[\mathrm{Et}_{4} \mathrm{~N}\right] \mathrm{Cl}$ were heated in THF using microwave irradiation. The resulting $[\mathrm{NiCl}(\mathrm{Cp})(\mathrm{NHC})]$ complexes are air- and moisture stable in the solid state, and represent two new members of this valuable and practical class of nickel catalysts. The new species were fully characterised using methods including NMR spectroscopy and X-ray crystallography. When tested in model Suzuki-Miyaura crosscoupling reactions, these complexes were found to be active for the cross-coupling of aryl bromides and aryl chlorides.
\end{abstract}

\section{Introduction}

Nickel catalysis is currently an area of great interest, due to the potential for nickel to replace palladium in some catalytic processes, as well as its ability to perform a much wider range of reactions [1]. Nickel complexes bearing N-heterocyclic carbenes (NHCs) [2] are an interesting class of catalysts [3,4], due to the fascinating characteristics of NHC ligands, which can be designed to have a wide range of steric and electronic properties [5-7]. Nickel catalysts of the form [Ni(Cp)X(NHC)] have been shown to be versatile and relatively easy-to-handle nickel pre-catalysts for a range of transformations; these species are typically stable to air and moisture in the solid state and are therefore practical and accessible catalysts for a range of researchers [8]. Initial complexes of this motif were disclosed by Cowley and Jones, who prepared $\left[\mathrm{Ni}\left(\eta^{1}-\mathrm{Cp}\right)\left(\eta^{5}-\mathrm{Cp}\right)(\mathrm{IMes})\right]$ (1) from the reaction of the free carbene with nickelocene (IMes = 1,3-bis(2,4,6-trimethylphenyl)imidazol-2-ylidene) (Scheme 1a) [9]. Complexes of the form [ $\mathrm{NiCl}(\mathrm{Cp})(\mathrm{NHC})]$, such as complex $\mathbf{2}$, are typically prepared by simply heating nickelocene with the corresponding $\mathrm{NHC} \cdot \mathrm{HCl}$ salt, rendering these species highly accessible (Scheme 1b) [10]. After the initial work by Cowley and Jones, various other researchers have disclosed complexes of this form and tested them in crosscoupling reactions such as Buchwald-Hartwig amination [11], Suzuki-Miyaura cross-coupling [12], and ketone $\alpha$-arylation $[3,13]$. These species can also catalyse hydrosilylation reactions [14]. 
(a)
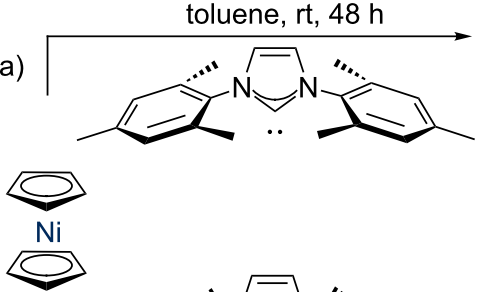

(b)

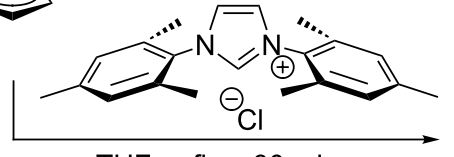

THF, reflux, $30 \mathrm{~min}$

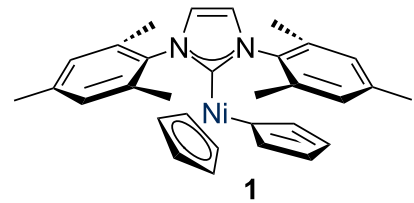

1

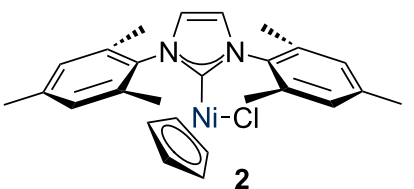

Scheme 1: Synthesis of $\left[\mathrm{Ni}\left(\eta^{1}-\mathrm{Cp}\right)\left(\eta^{5}-\mathrm{Cp}\right)(\mathrm{IMes})\right](\mathbf{1})$ and $[\mathrm{NiCl}(\mathrm{Cp})(\mathrm{IMes})](2)$.

Chatani and co-workers have recently reported that $\mathrm{ICy}$ ( $\mathrm{ICy}=$ 1,3-dicyclohexylimidazol-2-ylidene) is a superior ligand for the cross-coupling of aryl and benzyl methyl ethers with arylboronic acid esters, when used as the $\mathrm{HCl}$ or $\mathrm{HBF}_{4}$ salt combined with [Ni(COD $)_{2}$ ] [15-17]. In addition, a [Ni(OAc) $\left.)_{2}\right]$ $\mathrm{ICy} \cdot \mathrm{HCl}$ system was found to allow the cross-coupling of Grignard reagents with aryl ethers [18].

However, the identity of the active catalyst, which is formed in situ in these reactions, is as yet unknown, and might be a monoor bis-NHC complex. We therefore decided to prepare and test $[\mathrm{NiCl}(\mathrm{Cp})(\mathrm{ICy})](3)$ (closely related to [ $\mathrm{NiCl}(\mathrm{Cp})(\mathrm{IDD})](4))$ in some model catalytic reactions, to discover whether the favourable properties of ICy in cross-coupling catalysis could be combined with the ease of synthesis and handling of the nickel half-sandwich motif. Advantages to the use of welldefined catalytic species include that the catalyst and ligand are delivered in a specific and known ratio (in this case 1:1), and that there is no need for a 'pre-reaction' to combine ligand and metal which are both typically added in relatively low concentrations.

\section{Results and Discussion}

\section{Catalyst synthesis}

Nolan reported that the ICy and $\mathrm{I} t$-Bu complexes could not be prepared by heating nickelocene with $\mathrm{NHC} \cdot \mathrm{HCl}$ salts $(\mathrm{I} t-\mathrm{Bu}=$ 1,3-di-tert-butylimidazol-2-ylidene) [19]. In addition, these salts are highly hygroscopic, and therefore difficult to prepare and purify. The tetrafluoroborate salts can be prepared in a one-pot procedure and are easy-to-handle non-hygroscopic white powders, so our first aim was to synthesise the target complexes from $\mathrm{NHC} \cdot \mathrm{HBF}_{4}$ and nickelocene. We were pleased to find that we could prepare $[\mathrm{NiCl}(\mathrm{Cp})(\mathrm{ICy})](3)$ by adding $\left[\mathrm{Et}_{4} \mathrm{~N}\right] \mathrm{Cl}$ to a suspension of $\mathrm{ICy} \cdot \mathrm{HBF}_{4}$ and $\left[\mathrm{Ni}(\mathrm{Cp})_{2}\right]$ in THF and heating the suspension at reflux for $6 \mathrm{~h}$ under an argon atmosphere (Scheme 2), in a manner analogous to that recently reported by Albrecht for the synthesis of triazolylidene-based complexes [20]. However, the yield was rather poor (ca. 20\%), so a better route was desired. Changing the solvent to refluxing anhydrous 1,4-dioxane did not improve yields, nor did increased reaction times, or the use of a slight excess of nickelocene. We suspected that the product might be thermally unstable in solution, and that competing decomposition might be reducing the yield. To test this, a purified sample of 3 was subjected to $\left[\mathrm{Et}_{4} \mathrm{~N}\right] \mathrm{Cl}$ in refluxing anhydrous 1,4-dioxane for $6 \mathrm{~h}$; the deep red solution turned pale and yielded a black precipitate, confirming this hypothesis.

Navarro reported that $[\mathrm{NiCl}(\mathrm{Cp})(\mathrm{NHC})]$ complexes can be prepared in much shorter reaction times by using microwave heating [21]. As the microwave apparatus heats the solvent directly, rather than applying heat to the outer walls of a glass vessel, it was proposed that this might allow for better yields. Optimisation of the reaction conditions $\left(20 \mathrm{~min}\right.$ at $110^{\circ} \mathrm{C}$ in

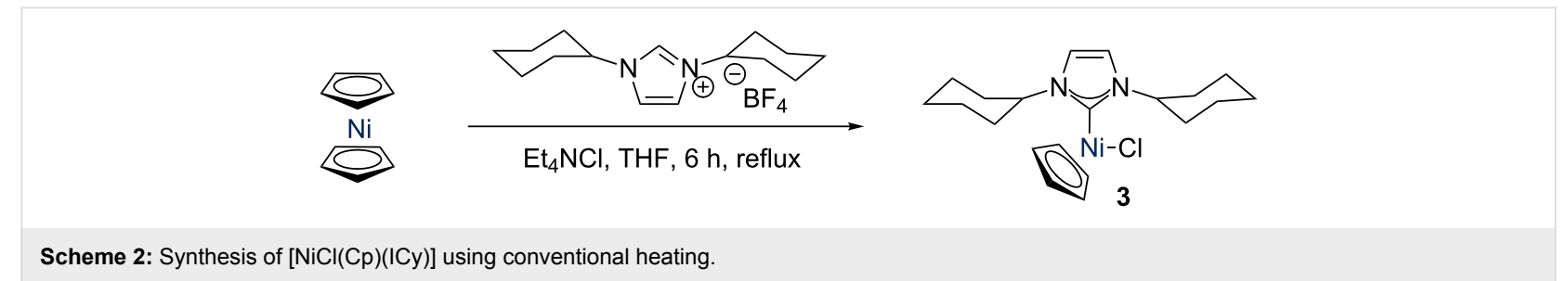


THF with 1.5 equiv nickelocene) allowed complex 3 to be isolated after work-up in analytically pure form, in $66 \%$ yield (Scheme 3a). Slightly lower yields were obtained when less nickelocene was added ( $43 \%$ yield, 1.1 equiv), while a further increase in stoichiometry to 2 equiv did not improve the yield.

With this new complex in hand, structurally similar examples were approached using the same methodology. IDD is a larger analogue of ICy (IDD = 1,3-dicyclododecylimidazol-2-ylidene) [22]; while it typically presents a similar steric profile to ICy in calculations of percent buried volume $\left(\% \mathrm{~V}_{\text {bur }}\right)$ using solid state structures [6], it is much larger and more flexible. It-Bu possesses significant steric bulk close to the metal centre, and has been known to allow the isolation of the interesting 16 electron three-coordinated $\left[\mathrm{Ni}(\mathrm{CO})_{2}(\mathrm{I} t\right.$-Bu) $]$ complex $(\mathrm{I} t-\mathrm{Bu}=1,3$-ditert-butylimidazol-2-ylidene) [23]. It has also been reported to trigger spontaneous $\mathrm{C}-\mathrm{H}$ activation upon coordination to $\mathrm{Rh}(\mathrm{I})$ and $\operatorname{Ir}(\mathrm{I})$ complexes, leading to 14 electron $\mathrm{Rh}(\mathrm{III})$ and $\mathrm{Ir}(\mathrm{III})$ species $[24,25]$. While the methodology applied to ICy worked for IDD (Scheme 3b), repeated attempts to isolate the It-Bu analogue were unsuccessful. Similarly, attempts to first prepare $\left[\mathrm{Ni}\left(\eta^{1}-\mathrm{Cp}\right)\left(\eta^{5}-\mathrm{Cp}\right)(\mathrm{I} t-\mathrm{Bu})\right]$ by the reaction of free $\mathrm{I} t$-Bu with [NiCp 2$]$ (analogous to Cowley's method) [9], envisaging subsequent replacement of the $\mathrm{Cp}$ ligand with chloride, were not successful.

The two new complexes were characterised by ${ }^{1} \mathrm{H}$ and ${ }^{13} \mathrm{C}\left\{{ }^{1} \mathrm{H}\right\}$ NMR spectroscopy, elemental analysis and X-ray crystallography (Figure 1). Selected crystallographic data can be found in Table 1, and some key bond lengths in Table 2. X-ray quality crystals were obtained by slow diffusion of pentane into a DCM solution of each complex. (a)

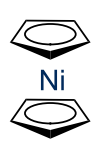

(1.5 equiv)

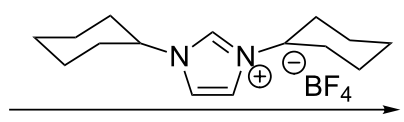

$\mathrm{Et}_{4} \mathrm{NCl}, \mathrm{THF}$

$20 \mathrm{~min}$, microwave, $110^{\circ} \mathrm{C}$

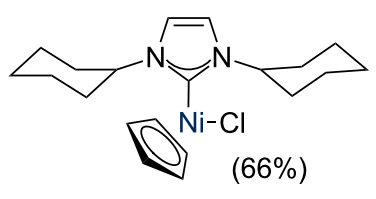

3

(b)
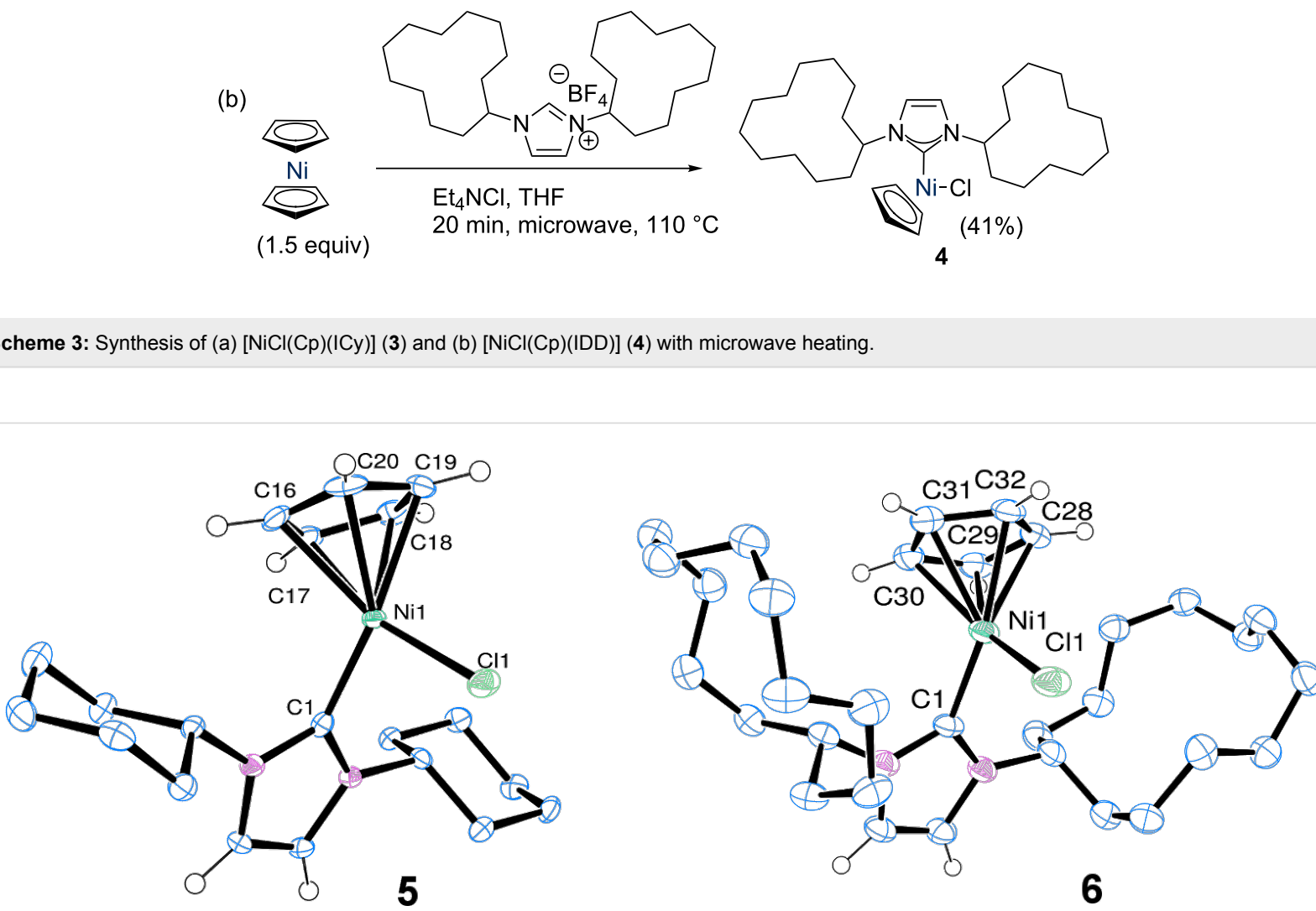

Figure 1: Molecular structures of complexes [NiCl(Cp)(ICy)] (3) (left) and [NiCl(Cp)(IDD)] (4) (right) as determined by single crystal X-ray diffraction. Displacement ellipsoids are drawn at $50 \%$ probability. Most $\mathrm{H}$ atoms are excluded for clarity. 
Table 1: Experimental data for single-crystal X-ray diffraction analyses of $[\mathrm{NiCl}(\mathrm{Cp})(\mathrm{ICy})]$ and $[\mathrm{NiCl}(\mathrm{Cp})(\mathrm{IDD})]$.

\begin{tabular}{lll} 
Structure & {$[\mathrm{NiCl}(\mathrm{Cp})(\mathrm{ICy})](3)$} & {$[\mathrm{NiCl}(\mathrm{Cp})(\mathrm{IDD})](4)$} \\
\hline CCDC ref. & 1049879 & 1049880 \\
Formula & $\mathrm{C}_{20} \mathrm{H}_{29} \mathrm{ClN}_{2} \mathrm{Ni}$ & $\mathrm{C}_{32} \mathrm{H}_{53} \mathrm{CIN}_{2} \mathrm{Ni}$ \\
Formula wt & $391.61 \mathrm{~g} \mathrm{~mol}^{-1}$ & $559.92 \mathrm{~g} \mathrm{~mol}^{-1}$ \\
Crystal system & orthorhombic & monoclinic \\
$a$ & $16.3306(3) \AA$ & $8.5685(2) \AA$ \\
$b$ & $10.2549(2) \AA$ & $13.9639(3) \AA$ \\
$c$ & $11.1879(2) \AA$ & $25.1631(6) \AA$ \\
$\beta$ & $90^{\circ}$ & $97.719(2)^{\circ}$ \\
V & $1873.62(6) \AA$ & $2983.48(12) \AA$ \\
Space group & $P c a 21$ & $P 21 / n$ \\
Z & 4 & 4 \\
$\mu$ & $1.182 \mathrm{~mm}^{-1}$ & $1.912 \mathrm{~mm}^{-1}$ \\
Reflns collected & 8979 & 11638 \\
Reflns unique & 4499 & 5828 \\
Reflns observed & 4029 & 4521 \\
$\mathrm{R}_{\text {int }}$ & 0.0316 & 0.0313 \\
Goodness of fit & 1.021 & 1.036 \\
R1 $(I>2 \sigma(I))$ & 0.0336 & 0.0427 \\
wR2 & 0.0683 & 0.1145 \\
& & \\
\hline
\end{tabular}

Table 2: Selected bond distances (units $\AA$ ).

\begin{tabular}{llll}
{$[\mathrm{NiCl}(\mathrm{Cp})(\mathrm{ICy})](3)$} & \multicolumn{2}{l}{$[\mathrm{NiCl}(\mathrm{Cp})(\mathrm{IDD})](4)$} \\
\hline $\mathrm{Ni}(1)-\mathrm{Cl}(1)$ & $2.1884(7)$ & $\mathrm{Ni}(1)-\mathrm{Cl}(1)$ & $2.1833(7)$ \\
$\mathrm{Ni}(1)-\mathrm{C}(16)$ & $2.136(3)$ & $\mathrm{Ni}(1)-\mathrm{C}(28)$ & $2.181(2)$ \\
$\mathrm{Ni}(1)-\mathrm{C}(17)$ & $2.056(3)$ & $\mathrm{Ni}(1)-\mathrm{C}(29)$ & $2.095(2)$ \\
$\mathrm{Ni}(1)-\mathrm{C}(18)$ & $2.160(3)$ & $\mathrm{Ni}(1)-\mathrm{C}(30)$ & $2.091(2)$ \\
$\mathrm{Ni}(1)-\mathrm{C}(19)$ & $2.137(3)$ & $\mathrm{Ni}(1)-\mathrm{C}(31)$ & $2.181(2)$ \\
$\mathrm{Ni}(1)-\mathrm{C}(20)$ & $2.192(3)$ & $\mathrm{Ni}(1)-\mathrm{C}(32)$ & $2.142(2)$
\end{tabular}

The ${ }^{1} \mathrm{H}$ NMR spectra show the expected features; a sharp singlet for the cyclopentadienyl ligand in each complex suggests that this ligand rotates faster than the NMR timescale, while a sharp singlet was also observed for the imidazol-2ylidene backbone protons. The cycloalkyl nature of the $\mathrm{N}$-substituents results in most of the proton signals for these species appearing as broad multiplets, even at high fields. The methine signal for the cycloalkyl substituents is discrete, appearing at $\delta_{\mathrm{H}}=6.01 \mathrm{ppm}$ for ICy and $\delta_{\mathrm{H}}=6.28 \mathrm{ppm}$ for IDD as a triplet of triplets and an apparent quintet, respectively. In the carbon NMR spectra, the imidazol-2-ylidene $\mathrm{C} 2$ signals resonate at $\delta_{\mathrm{C}}=157.0 \mathrm{ppm}$ (ICy) or $158.0 \mathrm{ppm}$ (IDD), compared to ca. $200 \mathrm{ppm}$ for complexes of saturated $\mathrm{N}, \mathrm{N}$ diarylimidazol-2-ylidenes and ca. $170 \mathrm{ppm}$ for their unsaturated counterparts [19]. This difference in $\delta_{\mathrm{C}}$ might result from the larger net electron-donating ability of ICy and IDD, as inferred from their lower TEP compared to IPr, IMes, and IPr*, for example [7,26,27].

The crystal structure data for $[\mathrm{NiCl}(\mathrm{Cp})(\mathrm{ICy})](3)$ reveal five different $\mathrm{Ni}-\mathrm{C}$ distances between the nickel centre and the cyclopentadienyl ligand, spanning a range of ca. $0.14 \AA$. These bond lengths are indicative of distortion from ideal $\eta^{5}$-geometry towards $\eta^{1}, \eta^{4}$-geometry (Table 2) [28]. In [NiCl(Cp)(IDD)] (4), the distances span a smaller range (ca. $0.09 \AA$ ). In both cases, the $\mathrm{Cl}-\mathrm{Ni}-\mathrm{C} 1$ angle is ca. $93-94^{\circ}$. The cyclohexyl rings adopt a chair conformation, while the cyclododecyl rings droop down around the metal centre, with the shortest $\mathrm{Cl}-\mathrm{H}$ distance being ca. $2.9 \AA$, approximately the sum of van der Waals radii of the two atoms.

\section{Assessment of catalytic activity}

With these new complexes in hand, their activity in some model cross-coupling reactions was examined. Ritleng and Chetcuti have deployed $[\mathrm{Ni}(\mathrm{Cp})(\mathrm{X})(\mathrm{NHC})]$ complexes in Suzuki-Miyaura cross-coupling reactions of 4'-bromoacetophenone and 4'-chloroacetophenone with phenylboronic acid (Scheme 4) [12]. It was therefore decided to study these reactions as part of our preliminary evaluation of these new complexes as potential pre-catalysts for cross-coupling reactions. The reactions were conducted in duplicate, and were analysed by ${ }^{1} \mathrm{H}$ NMR methods to calculate conversion. The new ICy- and IDD-bearing complexes were benchmarked against $[\mathrm{NiCl}(\mathrm{Cp})(\mathrm{IPr})](5)$ due to the ubiquity of this carbene in transition metal-mediated catalysis [29,30], and $\left[\mathrm{NiCl}(\mathrm{Cp})\left(\mathrm{IPr}^{*}\right)\right]$ (6) and $\left[\mathrm{NiCl}(\mathrm{Cp})\left(\mathrm{IPr}^{* \mathrm{OMe}}\right)\right]$ (7) due to their demonstrated competence as catalysts for the arylation of anilines [11].

The results from the cross-coupling reactions with 4'-bromoand 4'-chloroacetophenone are summarised in Table 3; running the latter reaction for more than $2 \mathrm{~h}$ did not lead to significant increases in conversion.

Unfortunately, we were unable to reproduce the literature conversion with $[\mathrm{NiCl}(\mathrm{Cp})(\mathrm{IPr})](87 \%)$ despite multiple attempts by different chemists. Different batches of toluene and base (with different water content) were screened, but we consistently achieved much lower conversions. Nevertheless, this provided a platform from which we could assess the new catalysts.

Surprisingly, the IPr* and IPr*OMe-bearing complexes performed rather poorly under these conditions. It was noted that in the Suzuki-Miyaura reactions, the catalysts bearing ICy or IDD changed colour (pink to orange-brown) more quickly, which may be suggestive of faster initiation. 


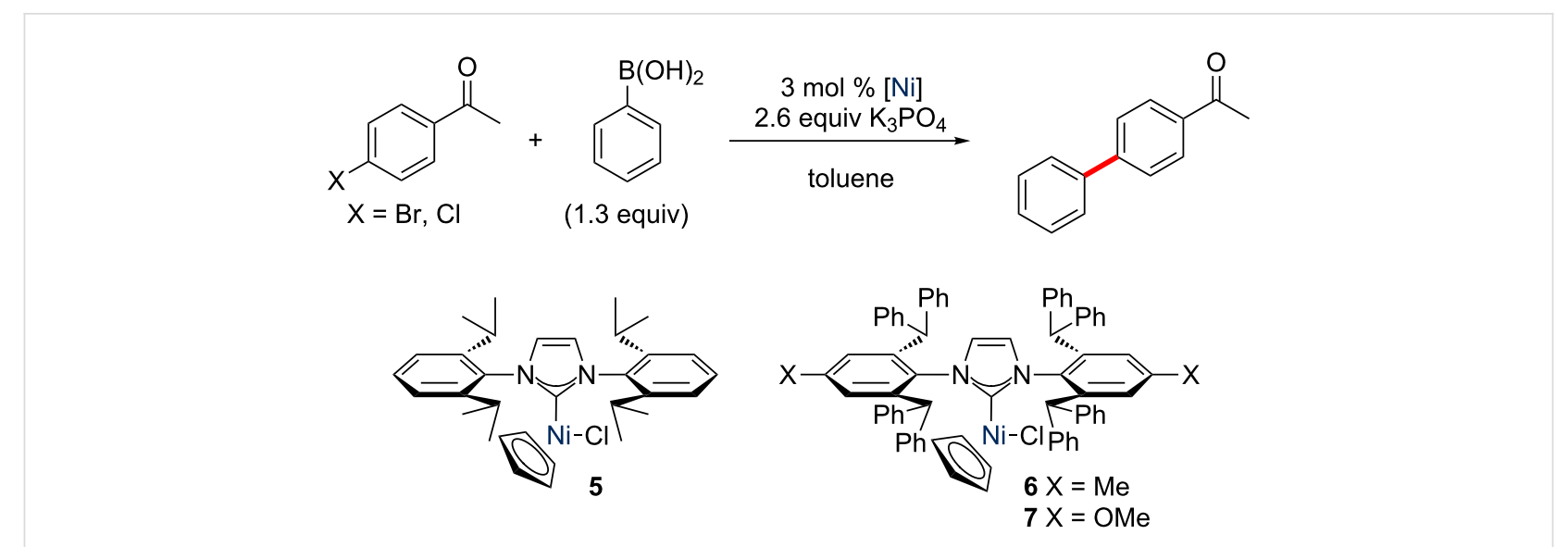

Scheme 4: Model Suzuki-Miyaura reaction for the evaluation of the new complexes as cross-coupling pre-catalysts.

Table 3: Results of test reactions with 4'-bromo- and 4'-chloroacetophenone, conducted using the conditions detailed in Scheme 4. ${ }^{a}$

\begin{tabular}{|c|c|c|c|c|}
\hline \multirow[t]{2}{*}{ Complex } & \multirow{2}{*}{$\begin{array}{c}\mathrm{X}=\mathrm{Br} \\
90^{\circ} \mathrm{C}, 0.5 \mathrm{~h}\end{array}$} & \multicolumn{3}{|c|}{$\mathrm{X}=\mathrm{Cl}$} \\
\hline & & $110^{\circ} \mathrm{C}, 0.5 \mathrm{~h}$ & $110^{\circ} \mathrm{C}, 2 \mathrm{~h}$ & $110^{\circ} \mathrm{C}, 4 \mathrm{~h}$ \\
\hline$[\mathrm{NiCl}(\mathrm{Cp})(\mathrm{IPr})](5)$ & $41 \%$ & $39 \%$ & $39 \%$ & $39 \%$ \\
\hline$[\mathrm{NiCl}(\mathrm{Cp})(\mathrm{ICy})](3)$ & $69 \%$ & $38 \%$ & $49 \%$ & $65 \%$ \\
\hline$[\mathrm{NiCl}(\mathrm{Cp})(\mathrm{IDD})](4)$ & $40 \%$ & $43 \%$ & $53 \%$ & $54 \%$ \\
\hline$\left[\mathrm{NiCl}(\mathrm{Cp})\left(\mathrm{IPr}^{*}\right)\right](\mathbf{6})$ & $22 \%$ & $20 \%$ & $27 \%$ & $N D^{b}$ \\
\hline$\left[\mathrm{NiCl}(\mathrm{Cp})\left(\mathrm{IPr}^{* \mathrm{OMe}}\right)(7)\right.$ & $32 \%$ & $N D^{b}$ & $N D^{b}$ & $N D^{b}$ \\
\hline
\end{tabular}

aAll reactions conducted with $3 \mathrm{~mol} \%$ of pre-catalyst. The conversion to the cross-coupling product was determined in each case by integration of the ${ }^{1} \mathrm{H}$ NMR spectrum of the reaction mixture. Quoted results are an average of at least two independent experiments. ${ }^{b}$ Not determined.

Intrigued as to whether the more electron-donating nature of ICy and IDD, as inferred from their lower TEP [22,31], might influence their oxidative addition reactivity, the cross-coupling of 4'-chloroacetophenone and phenylboronic acid was investigated. These experiments suggest that the ICy and IDD complexes are indeed slightly better catalysts for the crosscoupling of more challenging electrophiles. However, extension of these studies to 4-chloroanisole which is a challenging and electron-rich aryl chloride substrate, led to disappointing conversions (ca. $15 \%$ with $[\mathrm{NiCl}(\mathrm{Cp})(\mathrm{ICy})](3))$. This may be due to the thermal sensitivity of these complexes, or may suggest that the active species in Chatani's work is in fact a bis(NHC) complex. Further work is underway in our laboratory to understand the effect of NHC structure on cross-coupling reactivity, and to prepare and evaluate bis(ICy) complexes in catalysis.

\section{Conclusion}

We have prepared two new half-sandwich Ni(II) complexes, which until recently had been missing relatives in this practical and useful family of pre-catalysts. X-ray crystallographic analyses suggest a tendency towards $\eta^{1}, \eta^{4}$-coordination of the cyclopentadienyl ligand.

Preliminary catalyst testing in model Suzuki-Miyaura reactions suggest that these more electron-donating ligands yield complexes that are slightly more active for the cross-coupling of aryl chlorides but less thermally stable. Further studies to fully explore and apply the reactivity of the new complexes are presently underway in our laboratory.

\section{Experimental}

General. $\mathrm{ICy} \cdot \mathrm{HBF}_{4}$ and $\mathrm{I} t-\mathrm{Bu} \cdot \mathrm{HBF}_{4}$ were prepared according to literature procedures [22,25]. Complexes [ $\mathrm{NiCl}(\mathrm{Cp})(\mathrm{IPr})]$, $\left[\mathrm{NiCl}(\mathrm{Cp})\left(\mathrm{IPr}^{*}\right)\right]$ and $\left[\mathrm{NiCl}(\mathrm{Cp})\left(\mathrm{IPr}^{*} \mathrm{OMe}\right)\right]$ were prepared according to literature procedures [11,19]. Nickelocene was purchased from Strem or Alfa Aesar and stored at $-40{ }^{\circ} \mathrm{C}$ in the glovebox freezer. Anhydrous, oxygen-free THF and toluene were obtained from an Innovative Technologies PureSolv system $\left(<10\right.$ ppm $\mathrm{H}_{2} \mathrm{O}$, as measured by regular Karl Fischer analyses). Anhydrous 1,4-dioxane was obtained from SigmaAldrich and sparged with argon before use. $\left[\mathrm{Et}_{4} \mathrm{~N}\right] \mathrm{Cl}$ was 
purchased from Alfa Aesar and dried by heating under vacuum. Reactions under microwave irradiation were carried out using a Biotage apparatus in crimp-cap microwave vials equipped with magnetic stirrer bars.

NMR spectra were acquired using Bruker AV3-400, AV-400, AV3-500HD and AVII-600 spectrometers at $300 \mathrm{~K} .{ }^{1} \mathrm{H}$ NMR chemical shifts are reported in ppm referenced to residual solvent signals, while ${ }^{13} \mathrm{C}\left\{{ }^{1} \mathrm{H}\right\}$ NMR chemical shifts are reported referenced to deuterated solvent signals [32]. 2D experiments such as $\left[{ }^{1} \mathrm{H},{ }^{1} \mathrm{H}\right] \mathrm{COSY},\left[{ }^{1} \mathrm{H},{ }^{13} \mathrm{C}\right] \mathrm{HSQC}$ and $\left[{ }^{1} \mathrm{H},{ }^{13} \mathrm{C}\right] \mathrm{HMBC}$ were used where necessary to assign chemical shifts. Elemental analyses were conducted using a Perkin Elmer 2400 Series II instrument. X-ray crystallographic analyses were undertaken with samples mounted in oil at 123(2) $\mathrm{K}$ using an Oxford Diffraction diffractometer equipped with a CCD detector. All structures were refined against $\mathrm{F}^{2}$ and to convergence using all unique reflections and the program Shelxl-97 [33].

IDD·HBF 4 . Paraformaldehyde $(411 \mathrm{mg}, 13.7 \mathrm{mmol})$ was suspended in toluene $(25 \mathrm{~mL})$ and cyclododecylamine $(2.51 \mathrm{~g}$, $13.7 \mathrm{mmol}$ ) was added. The reaction was stirred at room temperature for $3 \mathrm{~h}$, and then cooled to $0{ }^{\circ} \mathrm{C}$ in an ice bath. A further portion of cyclododecylamine $(2.48 \mathrm{~g}, 13.5 \mathrm{mmol})$ was added, followed by the careful addition of aqueous $\mathrm{HBF}_{4}$ solution (48 wt \%, $2 \mathrm{~mL}, 1.34 \mathrm{~g}, 15.3 \mathrm{mmol}$ ). After the reaction was warmed to room temperature, aqueous glyoxal solution (40 wt \%, $2 \mathrm{~mL}, 1.01 \mathrm{~g}, 17.4 \mathrm{mmol}$ ) was added and the reaction was heated to $40^{\circ} \mathrm{C}$ and stirred vigorously overnight. The reaction was quenched with sat. aqueous $\mathrm{NaHCO}_{3}$ solution and filtered on a sintered frit. The resulting solid was washed on the frit with diethyl ether until the solid was white. Drying in a vacuum oven overnight at $50{ }^{\circ} \mathrm{C}$ yielded the title compound as a free-flowing white solid. Yield: $6.32 \mathrm{~g}$ (12.9 mmol, 95\%). ${ }^{1} \mathrm{H} \mathrm{NMR}\left(\mathrm{CDCl}_{3}, 400 \mathrm{MHz}\right) \delta_{\mathrm{H}} 9.13(\mathrm{~s}, 1 \mathrm{H}, \mathrm{NCHN}), 7.30(\mathrm{~s}$, $2 \mathrm{H}, \mathrm{N}(\mathrm{CH})_{2} \mathrm{~N}$ ), 4.58 (quint., ${ }^{3} J_{\mathrm{HH}}=5.6 \mathrm{~Hz}, 2 \mathrm{H}, \mathrm{NCHR}_{2}$ ), 2.16-2.00 (m, 4H, $\left.\mathrm{CH}_{2}\right), 1.82-1.71\left(\mathrm{~m}, 4 \mathrm{H}, \mathrm{CH}_{2}\right), 1.56-1.24$ $\left(\mathrm{m}, 36 \mathrm{H}, \mathrm{CH}_{2}\right) ;{ }^{13} \mathrm{C}\left\{{ }^{1} \mathrm{H}\right\} \mathrm{NMR}\left(\mathrm{CDCl}_{3}, 151 \mathrm{MHz}\right) \delta_{\mathrm{C}} 134.5$ $(\mathrm{NCN}), 120.9\left(\mathrm{~N}(\mathrm{CH})_{2} \mathrm{~N}\right), 59.0\left(\mathrm{NCHR}_{2}\right), 30.4\left(\mathrm{CH}_{2}\right), 23.6$ $\left(\mathrm{CH}_{2}\right), 23.5\left(\mathrm{CH}_{2}\right), 23.4\left(\mathrm{CH}_{2}\right), 21.5\left(\mathrm{CH}_{2}\right)$. Even at high field (14.1 T), not all $\mathrm{CH}_{2}$ signals could be successfully resolved. Anal. calcd. for $\mathrm{C}_{27} \mathrm{H}_{49} \mathrm{BF}_{4} \mathrm{~N}_{2}$ : C, 66.39; H, 10.11; N, 5.73; found: C, 65.96; H, 10.47; N, 5.76;

[NiCl(Cp)(ICy)]. In the glovebox, a microwave vial with stir bar was charged with nickelocene $(75.1 \mathrm{mg}, 0.398 \mathrm{mmol}$, 1.5 equiv), $\mathrm{ICy} \cdot \mathrm{HBF}_{4}(84.6 \mathrm{mg}, 0.263 \mathrm{mmol}, 1$ equiv) and $\left[\mathrm{Et}_{4} \mathrm{~N}\right] \mathrm{Cl}$ (43.7 $\mathrm{mg}, 0.264 \mathrm{mmol}, 1$ equiv) and the cap was secured with parafilm. Outside the glovebox, under a flow of argon, anhydrous THF ( $3 \mathrm{~mL})$ was added and the vial was sealed with a crimp cap. The reaction was heated to $110^{\circ} \mathrm{C}$ for $20 \mathrm{~min}$ in the microwave, during which time the solution changed the colour from green to red/purple. The THF was removed and the residue was taken up in hot toluene and filtered. The volume was reduced to ca. $1 \mathrm{~mL}$, and then hexane was added to precipitate the product. The green solution was decanted, and the solid was washed with hexane and dried under high vacuum to yield the product as a pink powder. Yield: $68.6 \mathrm{mg}(0.175 \mathrm{mmol}, 66 \%) .{ }^{1} \mathrm{H} \mathrm{NMR}\left(\mathrm{CDCl}_{3}\right.$, $400 \mathrm{MHz}) \delta_{\mathrm{H}} 6.94\left(\mathrm{~s}, 2 \mathrm{H}, \mathrm{N}(\mathrm{CH})_{2} \mathrm{~N}\right), 6.01\left(\mathrm{tt},{ }^{3} J_{\mathrm{HH}}=12,3.9\right.$ $\mathrm{Hz}, 2 \mathrm{H}, \mathrm{NCHR}_{2}$ ), 5.20 (s, 5H, CpH), 2.49-2.36 (m, 2H, Cy $\mathrm{CH}_{2}$ ), 2.10-1.92 (m, 6H, Cy CH 2$), 1.92-1.83$ (m, 2H, $\mathrm{Cy} \mathrm{CH}_{2}$ ), 1.81-1.47 (m, 8H, Cy $\left.\mathrm{CH}_{2}\right), 1.38-1.22\left(2 \mathrm{H}, \mathrm{m}, \mathrm{Cy} \mathrm{CH}_{2}\right)$; ${ }^{13} \mathrm{C}\left\{{ }^{1} \mathrm{H}\right\}$ NMR $\left(\mathrm{CDCl}_{3}, 101 \mathrm{MHz}\right) \delta_{\mathrm{C}} 157.0(\mathrm{NCN}), 118.9$ $\left(\mathrm{N}(\mathrm{CH})_{2} \mathrm{~N}\right), 91.6(\mathrm{Cp} \mathrm{CH}), 61.1\left(\mathrm{NCHR}_{2}\right), 34.4\left(\mathrm{Cy} \mathrm{CH}_{2}\right), 34.1$ $\left(\mathrm{Cy} \mathrm{CH}_{2}\right), 26.0\left(\mathrm{Cy} \mathrm{CH}_{2}\right), 25.8\left(\mathrm{Cy} \mathrm{CH}_{2}\right), 25.5\left(\mathrm{Cy} \mathrm{CH}_{2}\right)$; Anal. calcd. for $\mathrm{C}_{20} \mathrm{H}_{29} \mathrm{ClN}_{2} \mathrm{Ni}$ : C, 61.34; H, 7.46; N, 7.15; found: $\mathrm{C}$, $61.10 ; \mathrm{H}, 7.41 ; \mathrm{N}, 6.84$.

[NiCl(Cp)(IDD)]. In the glovebox, a microwave vial with stir bar was charged with nickelocene $(100.0 \mathrm{mg}, 0.529 \mathrm{mmol}$, 1.5 equiv), $\mathrm{IDD} \cdot \mathrm{HBF}_{4}(172.6 \mathrm{mg}, 0.353 \mathrm{mmol}, 1$ equiv) and $\left[\mathrm{Et}_{4} \mathrm{~N}\right] \mathrm{Cl}$ (58.4 $\mathrm{mg}, 0.352 \mathrm{mmol}, 1$ equiv) and the cap was secured with parafilm. Outside the glovebox, under a flow of argon, anhydrous THF $(5 \mathrm{~mL})$ was added and the vial was sealed with a crimp cap. The reaction was heated to $110^{\circ} \mathrm{C}$ for $20 \mathrm{~min}$ in the microwave, during which time the solution changed the colour from green to red. The solvent was removed and the residue was taken up in hot toluene and filtered. The volume was reduced to ca. $1 \mathrm{~mL}$, and then hexane was added to precipitate the product. The green solution was decanted, and the solid was washed with hexane and dried under high vacuum, to yield the product as a pink powder. Yield: $81.9 \mathrm{mg}$ (0.146 mmol, 41\%). ${ }^{1} \mathrm{H}$ NMR $\left(\mathrm{CDCl}_{3}, 400 \mathrm{MHz}\right) \delta_{\mathrm{H}} 6.95$ (s, $\left.2 \mathrm{H}, \mathrm{N}(\mathrm{CH})_{2} \mathrm{~N}\right), 6.28$ (app. quint., ${ }^{2} J_{\mathrm{HH}}=5.9 \mathrm{~Hz}, 2 \mathrm{H}, \mathrm{NCHR}_{2}$ ), $5.21(\mathrm{~s}, 5 \mathrm{H}, \mathrm{CpH}), 2.09-1.91\left(\mathrm{~m}, 4 \mathrm{H}, \mathrm{CH}_{2}\right), 1.91-1.73(\mathrm{~m}, 6 \mathrm{H}$, $\left.\mathrm{CH}_{2}\right), 1.73-1.39\left(\mathrm{~m}, 34 \mathrm{H}, \mathrm{CH}_{2}\right) ;{ }^{13} \mathrm{C}\left\{{ }^{1} \mathrm{H}\right\} \mathrm{NMR}\left(\mathrm{CDCl}_{3}\right.$, $150 \mathrm{MHz}) \delta_{\mathrm{C}} 158.0(\mathrm{NCN}), 119.6\left(\mathrm{~N}(\mathrm{CH})_{2} \mathrm{~N}\right), 91.8(\mathrm{Cp} \mathrm{CH})$, $59.2\left(\mathrm{NCHR}_{2}\right), 31.4\left(\mathrm{CDD} \mathrm{CH}_{2}\right), 31.2\left(\mathrm{CDD} \mathrm{CH}_{2}\right), 24.3(\mathrm{CDD}$ $\left.\mathrm{CH}_{2}\right), 24.1(\mathrm{CDD} \mathrm{CH}), 23.9\left(\mathrm{CDD} \mathrm{CH}_{2}\right), 23.81\left(\mathrm{CDD} \mathrm{CH}_{2}\right)$, $\left.23.78\left(\mathrm{CDD} \mathrm{CH}_{2}\right), 23.5(\mathrm{CDD} \mathrm{CH})_{2}\right), 22.5\left(\mathrm{CDD} \mathrm{CH}_{2}\right), 22.1$ $\left(\mathrm{CDD} \mathrm{CH}_{2}\right)$; Anal. calcd. for $\mathrm{C}_{32} \mathrm{H}_{53} \mathrm{ClN}_{2} \mathrm{Ni}$ : C, 68.64; H, 9.54; $\mathrm{N}, 5.00$; found: $\mathrm{C}, 68.54 ; \mathrm{H}, 9.64 ; \mathrm{N}, 4.88$.

General procedure for Suzuki-Miyaura reactions. A reaction tube or Schlenk flask was charged with 4'-bromoacetophenone or 4'-chloroacetophenone (1 mmol), $\mathrm{PhB}(\mathrm{OH})_{2}$ (1.3 mmol, 1.3 equiv), nickel complex and $\mathrm{K}_{3} \mathrm{PO}_{4}(2.6 \mathrm{mmol}$, 2.6 equiv) and closed with a septum. Anhydrous toluene $(3 \mathrm{~mL})$ was added via syringe, and the vial was inserted into a preheated oil bath and stirred vigorously. The septum was removed 
and the reaction mixture was filtered through celite and stripped of solvent. A sample of this was then taken up in chloroform- $d$ for ${ }^{1} \mathrm{H}$ NMR spectroscopic analysis. Conversion was assessed from the relative integrals of the resonances corresponding to the product at $\delta_{\mathrm{H}}=2.63 \mathrm{ppm}$ (4'-phenylacetophenone) and the starting material at $\delta_{\mathrm{H}}=2.56 \mathrm{ppm}$ (4'-bromoacetophenone) or $\delta_{\mathrm{H}}=2.58 \mathrm{ppm}$ (4'-chloroacetophenone). Slightly lower (by ca. $5 \%$ ) conversions were obtained in Schlenk flasks versus sealed tubes.

\section{Supporting Information}

\section{Supporting Information File 1}

Crystal structure data for new complexes.

[http://www.beilstein-journals.org/bjoc/content/

supplementary/1860-5397-11-235-S1.cif]

\section{Supporting Information File 2}

NMR spectra for compounds and complexes.

[http://www.beilstein-journals.org/bjoc/content/

supplementary/1860-5397-11-235-S2.pdf]

\section{Acknowledgements}

We thank the University of Strathclyde for funding a Chancellor's Fellowship for DJN, and the Carnegie Trust for funding an Undergraduate Vacation Scholarship for LM. We are grateful to the following specialists and technical staff for their assistance: Mr Craig Irving, Dr John Parkinson (NMR spectroscopy), Mr Alexander Clunie (elemental analyses), Ms Patricia Keating (GC and GC-MS), and Mr Gavin Bain (solvent purification system). We thank Professors Peter Skabara and Nicholas Tomkinson for allowing us to use their microwave equipment, and Professors Jonathan Percy and William Kerr for affording us access to their laboratory apparatus.

\section{References}

1. Tasker, S. Z.; Standley, E. A.; Jamison, T. F. Nature 2014, 509, 299-309. doi:10.1038/nature13274

2. Hopkinson, M. N.; Richter, C.; Schedler, M.; Glorius, F. Nature 2014, 510, 485-496. doi:10.1038/nature13384

3. Prakasham, A. P.; Ghosh, P. Inorg. Chim. Acta 2014, 431, 61-100. doi:10.1016/j.ica.2014.11.005

4. Henrion, M.; Ritleng, V.; Chetcuti, M. J. ACS Catal. 2015, 5, 1283-1302. doi:10.1021/cs5014927

5. Dröge, T.; Glorius, F. Angew. Chem., Int. Ed. 2010, 49, 6940-6952. doi:10.1002/anie.201001865

6. Clavier, H.; Nolan, S. P. Chem. Commun. 2010, 46, 841-861. doi:10.1039/b922984a

7. Nelson, D. J.; Nolan, S. P. Chem. Soc. Rev. 2013, 42, 6723-6753. doi:10.1039/c3cs60146c

8. Nelson, D. J. Eur. J. Inorg. Chem. 2015, 2012-2027. doi:10.1002/ejic.201500061
9. Abernethy, C. D.; Clyburne, J. A. C.; Cowley, A. H.; Jones, R. A. J. Am. Chem. Soc. 1999, 121, 2329-2330. doi:10.1021/ja983772s

10. Abernethy, C. D.; Cowley, A. H.; Jones, R. A. J. Organomet. Chem. 2000, 596, 3-5. doi:10.1016/S0022-328X(99)00557-4

11. Martin, A. R.; Makida, Y.; Meiries, S.; Slawin, A. M. Z.; Nolan, S. P. Organometallics 2013, 32, 6265-6270. doi:10.1021/om4004863

12. Ritleng, V.; Oertel, A. M.; Chetcuti, M. J. Dalton Trans. 2010, 39, 8153-8160. doi:10.1039/c0dt00021c

13. Henrion, M.; Chetcuti, M. J.; Ritleng, V. Chem. Commun. 2014, 50, 4624-4627. doi:10.1039/c4cc00959b

14. Postigo, L.; Royo, B. Adv. Synth. Catal. 2012, 354, 2613-2618. doi:10.1002/adsc.201200389

15. Tobisu, M.; Takahira, T.; Ohtsuki, A.; Chatani, N. Org. Lett. 2015, 17, 680-683. doi:10.1021/ol503707m

16. Furukawa, T.; Tobisu, M.; Chatani, N. Chem. Commun. 2015, 51 , 6508-6511. doi:10.1039/C5CC01378J

17. Tobisu, M.; Yasutome, A.; Kinuta, H.; Nakamura, K.; Chatani, N. Org. Lett. 2014, 16, 5572-5575. doi:10.1021/ol502583h

18. Tobisu, M.; Takahira, T.; Chatani, N. Org. Lett. 2015, 17, 4352-4355. doi:10.1021/acs.orglett.5b02200

19. Kelly, R. A., III; Scott, N. M.; Díez-González, S.; Stevens, E. D.; Nolan, S. P. Organometallics 2005, 24, 3442-3447. doi:10.1021/om0501879

20. Wei, Y.; Petronilho, A.; Mueller-Bunz, H.; Albrecht, M. Organometallics 2014, 33, 5834-5844. doi:10.1021/om500593s

21. Landers, B.; Navarro, O. Inorg. Chim. Acta 2012, 380, 350-353. doi:10.1016/j.ica.2011.09.055

22. Fortman, G. C.; Slawin, A. M. Z.; Nolan, S. P. Dalton Trans. 2010, 39, 3923-3930. doi:10.1039/c003214j

23. Dorta, R.; Stevens, E. D.; Hoff, C. D.; Nolan, S. P. J. Am. Chem. Soc. 2003, 125, 10490-10491. doi:10.1021/ja0362151

24. Dorta, R.; Stevens, E. D.; Nolan, S. P. J. Am. Chem. Soc. 2004, 126, 5054-5055. doi:10.1021/ja049545+

25. Scott, N. M.; Dorta, R.; Stevens, E. D.; Correa, A.; Cavallo, L.; Nolan, S. P. J. Am. Chem. Soc. 2005, 127, 3516-3526. doi:10.1021/ja043249f

26. Dorta, R.; Stevens, E. D.; Scott, N. M.; Costabile, C.; Cavallo, L.; Hoff, C. D.; Nolan, S. P. J. Am. Chem. Soc. 2005, 127, 2485-2495. doi:10.1021/ja0438821

27. Balogh, J.; Slawin, A. M. Z.; Nolan, S. P. Organometallics 2012, 31 , 3259-3263. doi:10.1021/om300104j

28. Cross, R. J.; Hoyle, R. W.; Kennedy, A. R.; Manojlović-Muir, L.; Muir, K. W. J. Organomet. Chem. 1994, 468, 265-271. doi:10.1016/0022-328X(94)80059-6

29. Huang, J.; Nolan, S. P. J. Am. Chem. Soc. 1999, 121, 9889-9890. doi:10.1021/ja991703n

30. Arduengo, A. J., III; Krafczyk, R.; Schmutzler, R.; Craig, H. A.; Goerlich, J. R.; Marshall, W. J.; Unverzagt, M. Tetrahedron 1999, 55, 14523-14534. doi:10.1016/S0040-4020(99)00927-8

31. Kelly, R. A., III; Clavier, H.; Giudice, S.; Scott, N. M.; Stevens, E. D.; Bordner, J.; Samardjiev, I.; Hoff, C. D.; Cavallo, L.; Nolan, S. P. Organometallics 2008, 27, 202-210. doi:10.1021/om701001g

32. Fulmer, G. R.; Miller, A. J. M.; Sherden, N. H.; Gottlieb, H. E.; Nudelman, A.; Stoltz, B. M.; Bercaw, J. E.; Goldberg, K. I. Organometallics 2010, 29, 2176-2179. doi:10.1021/om100106e

33. Sheldrick, G. M. Acta Crystallogr., Sect. A 2008, 64, 112-122. doi:10.1107/S0108767307043930 


\section{License and Terms}

This is an Open Access article under the terms of the Creative Commons Attribution License

(http://creativecommons.org/licenses/by/2.0), which permits unrestricted use, distribution, and reproduction in any medium, provided the original work is properly cited.

The license is subject to the Beilstein Journal of Organic Chemistry terms and conditions:

(http://www.beilstein-journals.org/bjoc)

The definitive version of this article is the electronic one which can be found at:

$\underline{\text { doi:10.3762/bjoc. } 11.235}$ 